\title{
Expression of the mau gene cluster of Paracoccus denitrificans is controlled by MauR and a second transcription regulator
}

\author{
Cécile Delorme, ${ }^{1}$ Tako T. Huisman, ${ }^{2}$ Willem N. M. Reijnders, ${ }^{1}$ \\ Yin-Lay Chan, ${ }^{3}$ Nellie Harms, ${ }^{1}$ Adriaan H. Stouthamer ${ }^{1}$ \\ and Rob J. M. van Spanning ${ }^{1}$
}

Author for correspondence: Rob J. M. van Spanning. Tel: +3120 444 7179. Fax: +3120444 7229. e-mail: spanning@bio.vu.nl

\footnotetext{
1,2 Departments of Microbial Physiology ${ }^{1}$ and Molecular Microbiology2, Faculty of Biology, Biocentrum Amsterdam, Vrije Universiteit, De Boelelaan 1087, NL-1081 HV, The Netherlands

3 Microbiology Research Centre Holland, Hudsonstraat 68, 1057 SN Amsterdam, The Netherlands
}

The mau gene cluster of Paracoccus denitrificans constitutes 11 genes (10 are located in the transcriptional order mauFBEDACJGMN ; the 11th, mauR, is located upstream and divergently transcribed from these genes) that encode a functional methylamine-oxidizing electron transport branch. The mauR gene encodes a LysR-type transcriptional activator essential for induction of the mau operon. In this study, the characteristics of that process were established. By using lacz transcriptional fusions integrated into the genome of $P$. denitrificans, it was found that the expression of the mauR gene during growth on methylamine and/or succinate was not autoregulated, but proceeded at a low and constant level. The mauf promoter activity was shown to be controlled by MauR and a second transcriptional regulator. This activity was very high during growth on methylamine, low on succinate plus methylamine, and absent on succinate alone. MauR was overexpressed in Escherichia coli by using a T7 RNA polymerase expression system. Gel shift assays indicated that MauR binds to a 403 bp DNA fragment spanning the mauR-mauf promoter region. It is concluded from these results that the expression of the structural mau genes is dependent on MauR and its inducer, methylamine, as well as on another transcription factor. Both activators are required for high-level transcription from the mauf promoter. It is hypothesized that the two activators act synergistically to activate transcription: the effects of the two activators are not additive and either one alone activates the mauf promoter rather weakly.

Keywords: LysR, Paracoccus denitrificans, mau, methylamine dehydrogenase, regulation

\section{INTRODUCTION}

Paracoccus denitrificans is a Gram-negative soil bacterium that is able to grow under a variety of conditions. In the presence of oxygen, it can grow on the $\mathrm{C}_{\mathbf{1}}$ substrate methylamine as sole source of carbon and energy (Harms \& van Spanning, 1991). For growth on this substrate, methylamine dehydrogenase (MADH) and its obligate electron acceptor amicyanin are indispensable (Van der Palen et al., 1995; van Spanning et al., 1990b). Both proteins are specifically induced during growth on methylamine (Husain \& Davidson, 1985,

Abbreviation: MADH, methylamine dehydrogenase.
1987) while they are absent when succinate is also present in the growth medium (Page \& Ferguson, 1993; van Spanning et al., 1994). MADH is a periplasmic protein which catalyses the oxidation of methylamine to formaldehyde and ammonium. MADH has an $\alpha_{2} \beta_{2}$ composition, with molecular masses of 46.7 and $15.5 \mathrm{kDa}$ for the $\alpha$ and $\beta$ subunits, respectively (Husain $\&$ Davidson, 1985, 1987). The small subunit contains the tryptophan tryptophylquinone cofactor, which is constructed after linkage and modification of two specific tryptophan residues in the protein chain (McIntire et al., 1991).

The genes involved in methylamine metabolism are clustered in the man locus. The man locus of $P$. 
denitrificans constitutes 11 genes organized in the transcription order mauRFBEDACJGMN (Chistoserdov et al., 1992; Van der Palen et al., 1995; van Spanning et al., 1990b, 1994) (Fig. 1a). The mauB and mauA genes encode the large and small subunits of $\mathrm{MADH}$, respectively, while mauC encodes amicyanin. MauG is a peroxidase-like cytochrome $c$ suggested to be involved in the processing of the tryptophan tryptophylquinone cofactor (Chistoserdov et al., 1994; Van der Palen et al., 1995). MauFEDJMN are accessory proteins involved in maturation and/or transport of MADH to the periplasm. Similar mau loci or parts of them have been found in other methylamine-utilizing organisms, including Methylobacterium extorquens AM1, Methylophilus methylotrophus W3A1-NS and the closely related strain Thiobacillus versutus (Huitema et al., 1993; Lidstrom \& Chistoserdov, 1993; Ubbink et al., 1991). Induction of the mau gene cluster has been suggested to be under control of the regulatory gene mauR, which is located upstream of mauF and divergently transcribed from the structural mau genes (van Spanning et al., 1994).

MauR is a member of the LysR family of transcriptional regulatory proteins (for a review see Schell, 1993). In general, genes encoding LysR-type regulators are divergently transcribed from the operon they regulate and their expression is often subject to negative autoregulation (Malakooti \& Ely, 1994; Parke, 1996; Wang et al., 1992). Most LysR-type proteins activate transcription of target genes after binding of an inducer. They also share a sequence homology in the $\mathrm{N}$-terminal region including a helix-turn-helix DNA-binding motif (Henikoff et al., 1988). In the absence of inducer, the LysR-type activators bind to promoter regions via a partially symmetrical sequence containing the $\mathrm{T}-\mathrm{N}_{11}-\mathrm{A}$ motif, generally located $65 \mathrm{bp}$ upstream from the transcription start of the regulated gene (Coco et al., 1994; Goethals et al., 1992). The presence of inducer may cause additional interactions of the activator with DNA sequences near the -35 RNA polymerase binding site and/or relaxed DNA bending that results in transcription activation (Huang \& Schell, 1991; Parsek et al., 1995; Wang et al., 1992).

The aim of this study was to investigate further the characteristics of expression of the mau operon. The results indicate that MauR can bind to the mau promoter DNA region and fully activate the mau promoter, but only in the presence of an additional transcription regulator.

\section{METHODS}

Bacterial strains, plasmids and growth conditions. The strains and plasmids used are listed in Table 1. Escherichia coli strains were grown aerobically at $37^{\circ} \mathrm{C}$ in YT medium $(5 \mathrm{~g}$ yeast extract $\mathrm{l}^{-1}, 8 \mathrm{~g}$ tryptone $\mathrm{l}^{-1}$ and $\left.5 \mathrm{~g} \mathrm{NaCl}^{-1}\right)$. P. denitrificans was grown aerobically at $30^{\circ} \mathrm{C}$ in batch culture or on plates, either on rich medium [Brain Heart Infusion (BHI); Gibco] or on mineral salts medium supplemented with $100 \mathrm{mM}$ methylamine, $10 \mathrm{mM}$ choline or $25 \mathrm{mM}$ succinate as carbon and energy source. The mineral salts medium was as described by
Chang \& Morris (1962) but supplemented with $1 \mathrm{ml}$ trace elements solution $\mathrm{I}^{-1}$ (van Spanning et al., 1990a). When necessary, antibiotics were added to final concentrations of $100 \mu \mathrm{g}$ ampicillin $\mathrm{ml}^{-1}, 25 \mu \mathrm{g}$ kanamycin $\mathrm{ml}^{-1}, 40 \mu \mathrm{g}$ rifampicin $\mathrm{ml}^{-1}, 50 \mu \mathrm{g}$ streptomycin $\mathrm{ml}^{-1}, 20 \mu \mathrm{g}$ chloramphenicol $\mathrm{ml}^{-1}$ or $12 \cdot 5 \mu \mathrm{g}$ tetracycline $\mathrm{ml}^{-1}$.

$\boldsymbol{\beta}$-Galactosidase assay. Cells were grown on mineral salts medium supplemented with various carbon sources as described above and harvested during the exponential phase of growth. When both methylamine and succinate were present, cells were harvested in the early-exponential phase of growth (van Spanning et al., 1994). After the cells had been permeabilized with toluene, $\beta$-galactosidase activity was measured with ONPG as a chromogenic substrate as described by Miller (1972).

Expression of mauR in E. coli. E. coli BL21(DE3)(pLysS) transformed with plasmid pET9a or its derivative harbouring the $\operatorname{mauR}$ gene, plasmid pET.MauR (see Results), was grown in YT medium to an $\mathrm{OD}_{600}$ of $0 \cdot 4-0 \cdot 5$. Expression of the $\mathrm{T} 7$ RNA polymerase was induced by adding $0.4 \mathrm{mM}$ IPTG to the cultures, which were then grown for an additional $30 \mathrm{~min}$ (Studier et al., 1990). After induction, $200 \mu \mathrm{g}$ rifampicin (ml culture $)^{-1}$ was added and the culture was grown for another $90 \mathrm{~min}$. Cells were harvested by centrifugation, and resuspended in binding buffer containing $40 \mathrm{mM}$ Tris $/ \mathrm{HCl}$ (pH 7.5), $1 \mathrm{mM}$ EDTA, $1 \mathrm{mM}$ DTT and $60 \mathrm{mM} \mathrm{KCl}$. The cell suspensions were sonicated $(4 \times 30 \mathrm{~s})$ and centrifuged at $11000 \mathrm{~g}$ for $10 \mathrm{~min}$ to remove cell debris. The resulting cellfree extracts were stored at $-80^{\circ} \mathrm{C}$.

For the purification of the MauR protein, the cell-free extracts of the overproducing strain were dissolved in $10 \mathrm{mM}$ potassium phosphate buffer $(\mathrm{pH} 7 \cdot 1)$ containing $0.25 \mathrm{mM}$ EDTA and $15 \mathrm{mM} \beta$-mercaptoethanol, and were directly applied to an hydroxyapatite column (Bio-Rad), equilibrated with the same buffer. Proteins were eluted by using a linear gradient of $10-400 \mathrm{mM}$ potassium phosphate buffer. By using SDS-PAGE analysis, the collected fractions were tested for the presence of a $39 \mathrm{kDa}$ protein band corresponding to the size of MauR. MauR-containing fractions were pooled and subsequently dialysed against $10 \mathrm{mM}$ Tris/ $\mathrm{HCl}(\mathrm{pH} 7 \cdot 6)$ containing $0.25 \mathrm{mM}$ EDTA and $15 \mathrm{mM} \quad \beta$-mercaptoethanol (TEM buffer) for $2 \mathrm{~h}$. The dialysed sample was loaded onto a DEAE column (DE52), which was equilibrated with TEM buffer. The MauR protein was eluted from this column by using a linear salt gradient of $45-750 \mathrm{mM} \mathrm{KCl}$ in TEM buffer. MauR-containing fractions were then dialysed overnight against TEM buffer and stored at $-80^{\circ} \mathrm{C}$.

Preparation of the DNA probe used in the binding studies. Plasmid pPr471 was digested with BamHI and HindIII and the $0.4 \mathrm{~kb}$ fragment $(60 \mathrm{ng}$ ) containing the $\operatorname{mauR}-m a u F$ intergenic region (Fig. 1b) was extracted from the agarose gel and radiolabelled with $\left[\alpha_{-}{ }^{32} \mathrm{P}\right] \mathrm{dCTP}$ by filling the recessed ends with Klenow DNA polymerase.

Gel shift DNA-binding assays. Each binding mixture $(20 \mu \mathrm{l})$ contained 30000 c.p.m. of the ${ }^{32}$ P-labelled target DNA, $10 \mu \mathrm{g}$ of sonicated herring sperm DNA and various a mounts of cellfree extract containing MauR in binding buffer. The reaction mixture was incubated for $15 \mathrm{~min}$ at $30^{\circ} \mathrm{C}$ and then loaded onto a low-ionic-strength acrylamide gel as previously described by Ausubel et al. (1993). The gels were subsequently dried and autoradiographed with intensifying screens.

Gel electrophoresis, electroblotting and protein sequencing. Proteins were analysed by SDS-PAGE according to the method of Laemmli (1970). Proteins were then transferred to a PVDFtype membrane (ProBlott; Applied Biosystems) as previously 
Table 1. Bacterial strains and plasmids

\begin{tabular}{|c|c|c|}
\hline Strain/plasmid & Relevant characteristics & Source/reference \\
\hline \multicolumn{3}{|l|}{ Strains } \\
\hline \multicolumn{3}{|l|}{ E. coli } \\
\hline BL21(DE3)pLysS & $\begin{array}{l}\mathrm{F}^{-} d c m o m p T \mathbf{r}_{\mathrm{B}}^{-} \mathrm{m}_{\mathrm{B}}^{-} \text {lon 1(DE3), pLysS, } \\
\mathrm{Cm}^{\mathrm{r}}\end{array}$ & Novagen \\
\hline TG1 & $\begin{array}{l}\text { supE hsd } \Delta 5 \text { thi } \Delta\left(\text { lac-proAB) } \mathrm{F}^{\prime}(\text { traD36 }\right. \\
\left.\text { proAB lacl }{ }^{\mathrm{q}} \text { lacZ } \Delta \mathrm{M} 15\right)\end{array}$ & Sambrook et al. (1989) \\
\hline HB101 & recA bsdR hsdM strA pro leu thi & $\begin{array}{l}\text { Boyer \& Roulland-Dussoix } \\
(1969)\end{array}$ \\
\hline \multicolumn{3}{|l|}{ P. denitrificans } \\
\hline Pd1222 & $\begin{array}{l}\text { DSM413, Rif }{ }^{\mathrm{r}}, \mathrm{Spec}^{\mathrm{r}} \text {, enhanced } \\
\text { conjugation frequencies }\end{array}$ & De Vries et al. (1989) \\
\hline $\operatorname{Pd} 1222:: \operatorname{Pr} 541 \mathrm{a}$ & Pd1222, pPr541 integrated once & This work \\
\hline $\operatorname{Pd} 1222:: \operatorname{Pr} 541 b$ & $\operatorname{Pd} 1222, \operatorname{pPr} 541$ integrated twice & This work \\
\hline $\operatorname{Pd} 1222:: \operatorname{Pr} 471 \mathrm{a}$ & Pd1222, pPr471 integrated once & This work \\
\hline $\operatorname{Pd} 1222:: \operatorname{Pr} 471 b$ & Pd1222, pPr471 integrated twice & This work \\
\hline $\operatorname{Pd} 4721$ & $\operatorname{Pd} 1222, \operatorname{mau} R:: \mathrm{Km}^{\mathrm{r}}$ & van Spanning et al. (1994) \\
\hline $\operatorname{Pd} 4721:: \operatorname{Pr} 541 a$ & Pd4721, pPr541 integrated once & This work \\
\hline $\operatorname{Pd} 4721:: \operatorname{Pr} 541 b$ & Pd4721, pPr541 integrated twice & This work \\
\hline $\operatorname{Pd} 4721:: \operatorname{Pr} 471 \mathrm{a}$ & $\operatorname{Pd} 4721, \operatorname{pPr} 471$ integrated once & This work \\
\hline $\operatorname{Pd} 4721:: \operatorname{Pr} 471 b$ & Pd4721, pPr471 integrated twice & This work \\
\hline \multicolumn{3}{|l|}{ Plasmids } \\
\hline рET9a & $\mathrm{Km}^{\mathrm{r}}, \phi 10$ promoter & Novagen \\
\hline pET.MauR & pET9a, mauR & This work \\
\hline $\mathrm{pBS}(\mathrm{II}) \mathrm{KS}$ & oriV (colE1), Amp, lac $Z^{\prime}$ & Stratagene \\
\hline pMAU32 & $\begin{array}{l}\mathrm{pBS}(\mathrm{II}) \mathrm{KS}, \operatorname{mau} R, \operatorname{mau} R-\operatorname{mau} F \text { intergenic } \\
\text { region and } 5^{\prime} \text { end } \operatorname{mauF}\end{array}$ & This work \\
\hline pBK11 & $\mathrm{Sm}^{\mathrm{r}}$, Spec ${ }^{\mathrm{r}}$, lacZ promoter-probe vector & Kessler et al. (1992) \\
\hline $\operatorname{pPr} 541$ & pBK11, mauF promoter-lacZ fusion & This work \\
\hline pPr471 & pBK11, mauR promoter-lacZ fusion & This work \\
\hline pRK2020 & $\mathrm{Tc}^{\mathrm{r}}, \mathrm{pRK} 2013:: \operatorname{Tn} 10$ & Ditta et al. $(1980)$ \\
\hline
\end{tabular}

described by Towbin et al. (1979). The ProBlott membrane was stained with Coomassie Brilliant Blue and then the protein band with the size corresponding to that of MauR was excised, after which its $\mathrm{N}$-terminal sequence was determined. Protein concentrations were determined using a BCA protein assay (Pierce) with bovine serum albumin as a standard.

DNA manipulations. General cloning techniques were carried out essentially as described by Ausubel et al. (1993). Plasmid DNA was isolated from E. coli by the alkaline lysis method (Birnboim, 1983) and purified by using the Qiagen plasmid kit. DNA restriction fragments were purified from agarose gels with the Qiaex gel extraction kit (Qiagen). Using the acetyltrimethylammonium bromide procedure, genomic DNA from $P$. denitrificans was isolated from cultures harvested during the stationary phase of growth (van Spanning et al., 1990a).

Digested chromosomal DNA was subjected to agarose gel electrophoresis on $0.8 \%$ gels; the fragments were then denaturated and transferred to positively charged nylon membranes (Boehringer Mannheim) according to the method of Southern (1975). Probes were made by labelling DNA with DIG-dUTP (DIG Nucleic Acid Detection kit; Boehringer Mannheim). After hybridization, visualization of the positively reacting fragments was performed with the chemi- luminescent substrate CSPD (Lumigen-PPD; Boehringer Mannheim) essentially as described by the manufacturer.

Conjugations. Conjugations were carried out by streaking cells of donor and recipient strains together with the helper strain HB101(pRK2020) on BHI plates. After $1 \mathrm{~d}$ incubation at $30^{\circ} \mathrm{C}$, cells were collected and plated on selective media, after which the exconjugants were isolated.

\section{RESULTS}

\section{Construction of mau promoter-lacZ fusion vectors}

Two promoter-lacZ fusions were constructed; one to the mauF promoter $(\mathrm{pPr} 541)$ and the second to the mauR promoter ( $\mathrm{pPr} 471)$. The starting materials were the lacZ promoter-probe vector pBK11 (Kessler et al., 1992), and plasmid pMAU32, which was constructed by insertion of a $1.3 \mathrm{~kb} X m n \mathrm{I}-H$ indIII fragment (with $m a u R$ and the mau promoter region) into the pBluescript vector. For the construction of $\operatorname{pPr} 541$, a $0.4 \mathrm{~kb}$ HincII-BamHI fragment from pMAU32 (the HincII site is located in mauR; the BamHI site is located in the multiple cloning site of the vector), containing the $m a u R$ and mauF promoter regions and flanking regions, was 

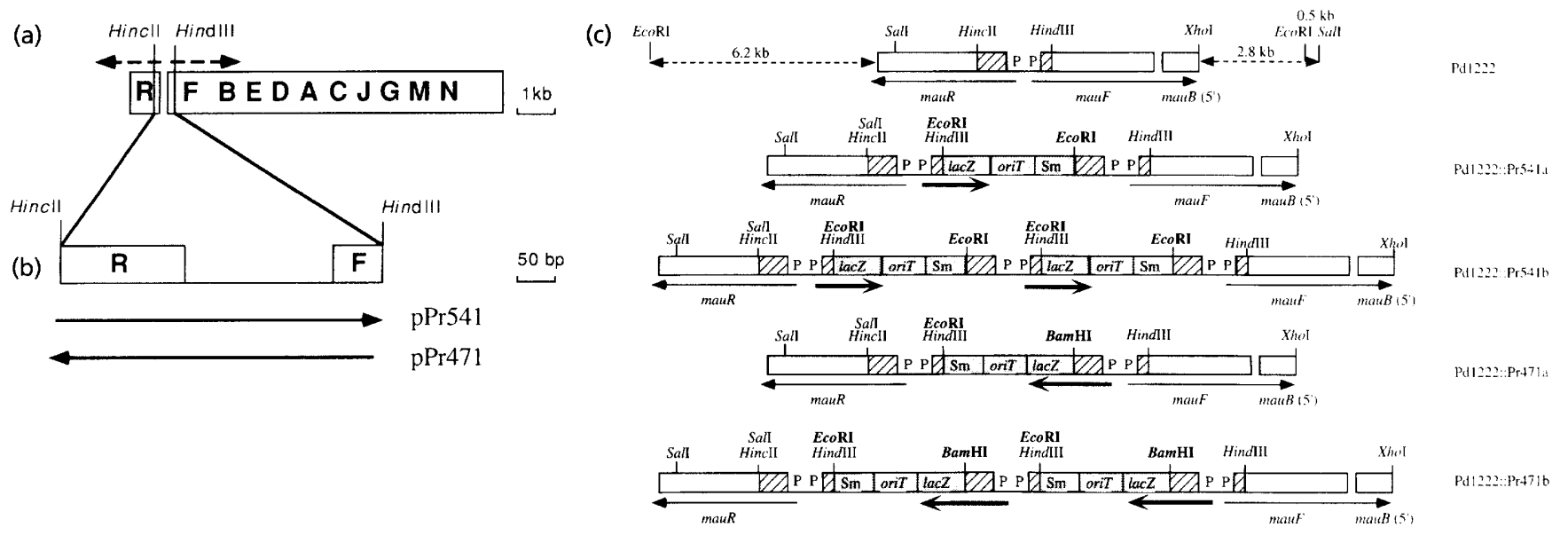

$\underline{0.25-\mathrm{kb}}$

\begin{abstract}
Fig. 1. Construction and integration into the genome of the lacZ promoter fusions pPr541 and pPr471. (a) Genetic organization of the mau operon. The direction of transcription is indicated by the direction of the dotted arrows above the genes. In (b) the promoter region is enlarged; relevant restriction sites of the pBluescript vector are indicated. The direction of the arrow indicates the position of the fragment relative to the transcription direction of lac $Z$. Details of the construction are given in Results. The $0.4 \mathrm{~kb}$ fragment shown in (b) was also used as probe in the Southern blot analysis and in the gel shift assays. (c) Genomic organization expected after integration of these fusions by homologous recombination. The different strains are shown to the right. The shaded boxes are elements of pBK11 $(7.9 \mathrm{~kb}$; not to scale), and the broken double-headed arrows at the top indicate the distances between relevant restriction sites located upstream and downstream. The mau promoter region ( $P$ P) sandwiched by the hatched boxes is the genomic part that was used for construction of pPr541 and pPr471. The direction of transcription is indicated by the direction of the thin arrows under the genes. The direction of the thick arrows indicates the position of the fragment relative to the transcription direction of lacz. Restriction sites in bold belong to the multiple cloning site of the vector.
\end{abstract}

cloned into the SmaI-BamHI sites of pBK11 upstream of the lacZ gene (Fig. 1b). The plasmid pPr471 was constructed by insertion of the same fragment in the opposite orientation into the polylinker of pBK11 (using HincII-EcoRI and SmaI-EcoRI sites for the insert and the vector, respectively). The $\mathrm{pPr} 471$ and $\mathrm{pPr} 541$ vectors were transferred by conjugation to $P$. denitrificans, the wild-type strain Pd1222 and the mutant strain Pd4721 (mauR:: $\mathrm{Km}^{\mathrm{r}}$ ). The exconjugants that had integrated the vector with the Pmau-lac $Z$ fusion into the chromosome by homologous recombination were selected for their resistance to streptomycin. A scheme showing the genomic organization expected after integration of these fusions by homologous recombination is shown in Fig. 1(c).

Southern analysis of these strains with the $0.4 \mathrm{~kb}$ fragment as a probe (Fig. 1b) revealed that both constructs were properly integrated within the chromosomal copy of the mau promoter region. In some cases the vectors were integrated twice at the same location, yielding an organization of two Pmau-lac $Z$ fusions in tandem. A typical example of these analyses is shown in Fig. 2. When the chromosomal DNA was digested with EcoRI (Fig. 2a), the probe hybridized with an approximately $12 \mathrm{~kb}$ DNA fragment of the wild-type strain Pd1222 (lane 4), with 4 and $7 \cdot 4 \mathrm{~kb}$ fragments of the insertion strains Pd1222::Pr541b and a (lanes 1 and 2), and with 13 and $7.4 \mathrm{~kb}$ fragments of the insertion strains Pd1222::Pr471b and a (lanes 3 and 5), as expected. The presence of faint $7 \cdot 0 \mathrm{~kb}$ bands in lanes 1 and 2 are most likely due to incomplete digestion of the chromosomal
DNA. Digestion with SalI (Fig. 2b) gave rise to a band of $4.3 \mathrm{~kb}$ which hybridized with the probe for the wild-type strain (lane 1), as expected. Two distinct bands of either $12.6 \mathrm{~kb}$ (lanes 3 and 4) or $20.9 \mathrm{~kb}$ (lanes 2 and 5) were obtained for the insertion strains, depending on whether one (Pd1222::Pr541a and Pr471a) or two (Pd1222:: $\operatorname{Pr} 541 b$ and $\operatorname{Pr} 471 b$ ) copies of the lacZ fusion vector had been integrated into the genome. As expected, similar band patterns were obtained with the insertion strains derived from the mutant strain Pd4721 (results not shown). All plasmid integrated derivatives of strains Pd1222 and Pd4721 were used for further analyses.

\section{$\boldsymbol{\beta}$-Galactosidase assays}

The eight different insertion strains were grown on succinate, on methylamine, or on a combination of the two carbon sources. After harvesting the cells, the transcriptional activities of the mau promoters, as reflected by the $\beta$-galactosidase activities, were assessed (Table 2). For supporting the growth of the mauR mutant strains, which are unable to grow on methylamine, a second substrate had to be supplied (choline or succinate) as source of carbon and energy in addition to the first substrate as inducer of the mau gene cluster (van Spanning et al., 1994). The $\beta$-galactosidase activities of the parent strains Pd1222 and Pd4721 were below 1 Miller unit.

The $\beta$-galactosidase activity of succinate-grown Pd1222::Pr541a was at background level, suggesting that the mauF promoter is inactive under those growth 
(a)

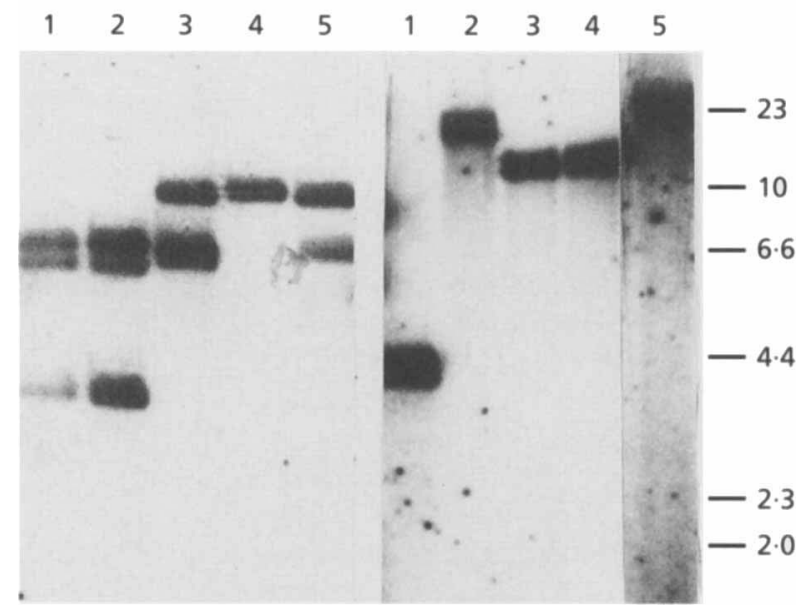

Fig. 2. Southern blot analysis of $P$. denitrificans plasmid integrant strains. (a) Southern blot of $P$. denitrificans chromosomal DNA digested with EcoRI. Lanes: 1, Pd1222::Pr541b; 2, Pd1222::Pr541a; 3, Pd1222::Pr471b; 4, Pd1222 wild-type strain; 5, Pd1222::Pr471a. (b) Southern blot of $P$. denitrificans chromosomal DNA digested with Sall. Lanes: 1, Pd1222; 2, Pd1222::Pr471b; 3, Pd1222::Pr471a; 4, Pd1222::Pr541a; 5, Pd1222::Pr541b. DNA fragments were visualized with the labelled $0.4 \mathrm{~kb}$ EcoRI-BamHI fragment of pPr471. The size of DIG-labelled DNA molecular size markers is indicated to the right (in kb).

conditions. In contrast, methylamine-grown Pd1222:: Pr541a cells displayed a 2000 -fold increase in $\beta$ galactosidase activity as compared with succinategrown cells (4 versus 8755 Miller units).

The mauF promoter activity in $\operatorname{Pd} 1222:: \operatorname{Pr} 541$ a cells grown on both succinate and methylamine was about 50 -fold lower than when they were grown in the presence of methylamine alone ( 148 versus 8755 Miller units), but higher than when they were grown in the presence of succinate alone. The mauF promoter activity in mutant strain Pd4721::Pr541a grown under the same conditions was reduced to background level, indicating that this activity is strictly dependent on MauR ( 2 versus 148 Miller units).

The $\beta$-galactosidase activity of the strain Pd1222:: Pr541a was much lower when the cells were grown on choline than when they were grown on methylamine 35 versus 8755 Miller units). The activity of the former cells, however, was significantly higher than that of the background level (35 versus 4 Miller units). Furthermore, this low level of activity of the mauF promoter was independent of the activator MauR, since it was also observed in the Pd4721::Pr541a strain.

When Pd1222::Pr541a cells were grown in the simultaneous presence of methylamine and choline, the transcriptional activity of the mauF promoter was very strong and only twofold lower than in the presence of methylamine alone (4007 versus 8755 Miller units). In $\operatorname{Pd} 4721$ ::Pr541a grown under the same conditions, this activity was strongly reduced (12 versus 4007 Miller units), but it was significantly higher than the background level.

In all cases, the strains carrying two copies of the lac $Z$ fusion, Pd1222::Pr541b or Pd4721::Pr541b, exhibited $\beta$-galactosidase activities approximately twofold higher than those carrying a single copy of the vector, Pd1222::Pr541a or Pd4721::Pr541a.

In contrast to the mauF promoter, the transcriptional activity of the mauR promoter was low and constant, irrespective of whether the strains were grown on methylamine and/or succinate. However, when the growth medium contained choline alone or choline with methylamine, the activity was always slightly higher.

\section{Table 2. Expression studies of the mauR and mauf promoters}

Cells were grown in mineral salts medium supplemented with a carbon source as indicated. After disruption of the cells with toluene, $\beta$-galactosidase activity was assayed with ONPG as substrate. All strains carry a genomic lac $Z$ fusion except the parent strains Pd1222 and Pd4721 added as control. MA, Methylamine; Succ, succinate; Chol, choline; Pr, promoter; -, no growth. Data are the mean of three independent determinations, each performed in triplicate. All standard deviations are within $15 \%$ of the mean.

\begin{tabular}{|c|c|c|c|c|c|c|}
\hline \multirow[t]{2}{*}{ Strain } & \multirow{2}{*}{ Relevant genetic characteristics } & \multicolumn{5}{|c|}{$\beta$-Galactosidase activity (Miller units) after growth on: } \\
\hline & & MA & Succ & $\mathbf{M A}+$ Succ & Chol & $\mathrm{MA}+\mathrm{Chol}$ \\
\hline Pd1222 & Parent strain & $<1$ & $<1$ & $<1$ & $<1$ & $<1$ \\
\hline $\operatorname{Pd} 4721$ & $\operatorname{mau} R:: \mathrm{Km}^{\mathrm{r}}$ & - & $<1$ & $<1$ & $<1$ & $<1$ \\
\hline $\operatorname{Pd} 1222:: \operatorname{Pr} 541 \mathrm{a}$ & $\operatorname{Pr} m a u F-l a c Z$ & 8755 & 4 & 148 & 35 & 4007 \\
\hline $\operatorname{Pd} 4721:: \operatorname{Pr} 541 a$ & $\operatorname{mauR}:: \mathrm{Km}^{\mathrm{r}}, \operatorname{Pr} \operatorname{mauF-lacZ}$ & - & 2 & 2 & 15 & 12 \\
\hline $\operatorname{Pd} 1222:: \operatorname{Pr} 541 b$ & $(\operatorname{Pr} \operatorname{man} F-l a c Z) \times 2$ & 16712 & 11 & 362 & 84 & 8186 \\
\hline $\operatorname{Pd} 4721:: \operatorname{Pr} 541 b$ & $\operatorname{mau} R:: \mathrm{Km}^{\mathrm{r}}(\operatorname{Pr} \operatorname{mauF-lacZ}) \times 2$ & - & 10 & 12 & 114 & 97 \\
\hline $\operatorname{Pd} 1222:: \operatorname{Pr} 471 \mathrm{a}$ & $\operatorname{Pr} m a u R-l a c Z$ & 19 & 16 & 17 & 48 & 26 \\
\hline $\operatorname{Pd} 4721:: \operatorname{Pr} 471 a$ & $\operatorname{mau} R:: \mathrm{Km}^{\mathrm{r}} \operatorname{Pr} \operatorname{mau} R-l a c Z$ & - & 15 & 21 & 37 & 33 \\
\hline $\operatorname{Pd} 1222:: \operatorname{Pr} 471 b$ & $(\operatorname{Pr} m a u R-l a c Z) \times 2$ & 30 & 30 & 33 & 81 & 55 \\
\hline $\operatorname{Pd} 4721:: \operatorname{Pr} 471 b$ & $\operatorname{mauR}:: \mathrm{Km}^{\mathrm{r}}(\operatorname{Pr} \operatorname{mauR}-l a c Z) \times 2$ & - & 25 & 38 & 79 & 85 \\
\hline
\end{tabular}




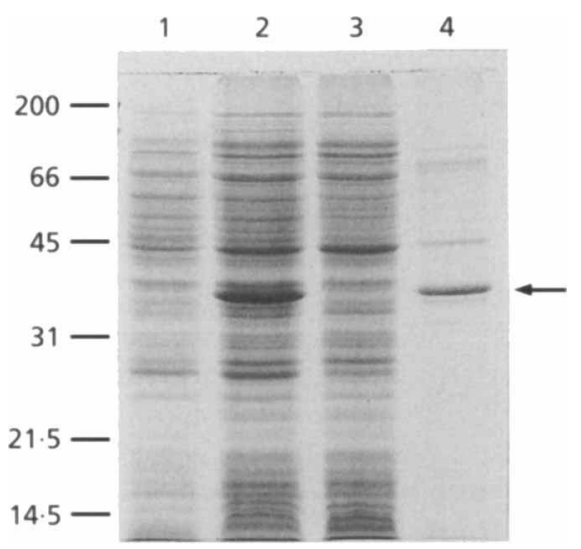

Fig. 3. Purification of the MauR protein from $E$. coli cell-free extracts overproducing MauR. Electrophoresis was performed on a $12.5 \%$ polyacrylamide gel containing $0.1 \%$ SDS and proteins were visualized by Coomassie Blue staining. Lanes: 1, cell extract of $E$. coli BL21(DE3)(pET.MauR) minus IPTG $(20 \mu \mathrm{g})$; 2, cell extract of $E$. coli BL21(DE3)(pET.MauR) plus IPTG $(20 \mu \mathrm{g})$; 3 , cell extract of $E$. coli BL21(DE3)(pET9a) plus IPTG $(20 \mu \mathrm{g}) ; 4$, purified MauR $(2 \mu \mathrm{g})$. Molecular mass markers (in $\mathrm{kDa}$ ) are indicated on the left. The arrow indicates the position of the 39 kDa mauR gene product.

Furthermore, the mauR mutants $\operatorname{Pd} 4721:: \operatorname{Pr} 471 \mathrm{a}$ and $\mathrm{b}$ displayed $\beta$-galactosidase activities similar to those of the corresponding wild-type strains Pd1222::Pr471a and $b$, respectively.

\section{Expression of MauR in E. coli}

Overexpression of mauR in E. coli was shown to be negatively affected when sequences upstream of the gene were cloned along with it. In order to avoid this negative effect, a translational fusion between the mauR gene and the promoter of the pET9a vector was generated. To achieve this, the mauR gene was amplified in a PCR with two primers that matched the upstream and downstream regions of the gene. The upstream primer $5^{\prime}$-AAGCTT-
CATATGAACTGGGACGACCTTCG-3' was slightly modified in order to introduce an NdeI site at the position of the ATG translational start codon. The downstream primer 5'-GAATTCGGATCCCTACACCGCGTCGCCGG-3' was equipped with a BamHI site. The resulting $0.9 \mathrm{~kb}$ PCR product was cut with NdeI and BamHI and cloned in pET9a, yielding pET.MauR. In this construct, the mauR coding region is now fused to the ATG start codon present on the T7 expression vector pET9a. Expression from the $\mathrm{T} 7$ promoter in $E$. coli BL21(DE3) harbouring either pET.MauR or pET9a was induced with IPTG. SDS-PAGE analysis of the cellfree extracts showed that a protein of approximately 39 $\mathrm{kDa}$ was expressed in E. coli BL21(DE3)(pET.MauR) upon induction with IPTG (Fig. 3, lane 2). The apparent molecular mass of this protein is in agreement with that predicted from the sequence translated from the mauR gene $(32 \mathrm{kDa})$. This protein band was absent in $E$. coli BL21(DE3)(pET9a) (Fig. 3, lane 3). The cell-free extracts overproducing the $39 \mathrm{kDa}$ protein were used for the purification of MauR. After two purification steps, first on a hydroxyapatite column and subsequently on a DEAE column (as described in Methods), a partially purified protein preparation containing some minor contaminants was obtained (Fig. 3, lane 4). Sequence analysis of the $\mathrm{N}$-terminus of this $39 \mathrm{kDa}$ protein band revealed the amino acid sequence MNWDDL, which was identical to that deduced from the sequence translated from the mauR gene, confirming that the overproduced protein was MauR.

\section{Binding of MauR to the mauR-mauF intergenic region}

To determine whether MauR binds to the mau promoter region, gel mobility shift assays were performed. Increasing amounts of cell-free extracts of $E$. coli BL21(DE3) harbouring either pET.MauR or the vector pET9a were incubated with a 403 bp HindIII-BamHI DNA fragment containing the mauR-mauF intergenic region and flanking regions (Fig. 4). A clear shift of the (a)

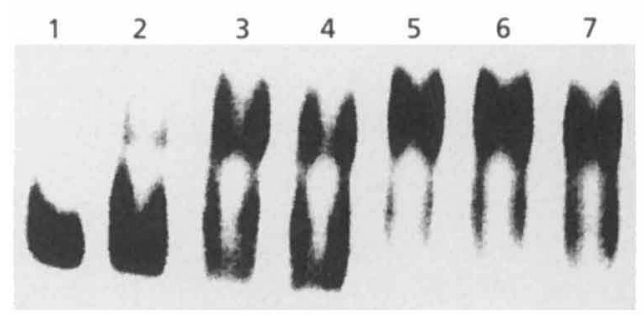

(b)

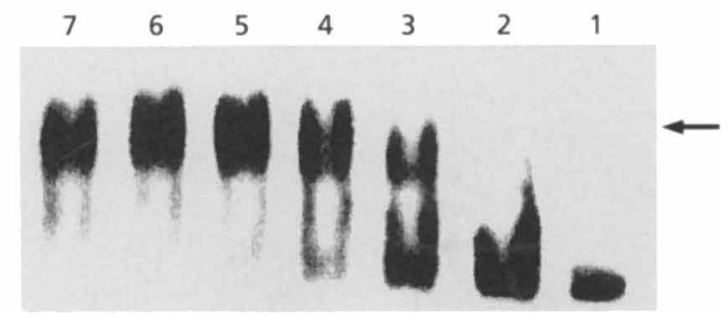

Fig. 4. Gel mobility shift assays of the HindllI-BamHI fragment containing mauR and mauF promoter regions with cell extracts overproducing MauR. Assays were performed by incubating IPTG-induced cell-free extracts of E. coli BL21(DE3) containing PET.MauR or pET9a with the labelled $403 \mathrm{bp} \mathrm{HindlII-BamHI}$ fragment in the absence of inducer (a) or in the presence of inducer, $1 \mathrm{mM}$ methylamine (b). Lanes: 1 , no extract added; $2,24 \mu \mathrm{g}$ cell-free extract of $E$. coli harbouring pET9a; $3,2 \mu \mathrm{g}$ cell-free extract of $E$. coli harbouring pET.MauR; $4,4 \mu \mathrm{g}$ cell-free extract of $E$. coli harbouring pET.MauR; $5,8 \mu \mathrm{g}$ cell-free extract of $E$. coli harbouring PET.MauR; $6,16 \mu \mathrm{g}$ cell-free extract of $E$. coli harbouring pET.MauR; 7 , $24 \mu \mathrm{g}$ cell-free extract of $E$. coli harbouring pET.MauR. The arrow indicates the position of the single electrophoretically retarded complex. 
labelled HindIII-BamHI fragment was observed when cell-free extracts of $E$. coli harbouring pET.MauR, in which $\operatorname{mauR}$ was expressed, were added to the assay mixture. In contrast, no retardation was observed when extracts harbouring the vector pET9a were used at similar concentrations. Increasing protein concentrations of cell-free extracts from $E$. coli harbouring pET.MauR $(2-24 \mu \mathrm{g})$ caused an increasing amount of the labelled fragment to show retarded mobility (lanes $3-7)$. At protein levels higher than $30 \mu \mathrm{g}$, non-specific binding activity was observed (not shown). High concentrations of carrier DNA (10 $\mu \mathrm{g}$ herring sperm DNA) in the binding reaction were required in order to prevent non-specific binding. The presence of methylamine in this assay (Fig. 4 b) did not alter the results.

\section{DISCUSSION}

Here we provide evidence that MauR, which is a LysRtype transcriptional activator, is able to bind to the promoter DNA region upstream of the mau gene cluster, and is essential for the transcription process during growth on methylamine. The concentration of MauR appeared to be relatively constant in the cells during growth on either succinate or methylamine. High levels of $m a u F$ gene expression, however, were only found when the cells were grown on methylamine. The latter molecule is thus very likely to be the chemical signal for activation of MauR. Indeed, many members of the LysR-type family are activated by the same molecule as that which is metabolized by the products of the genes that they control (Schell, 1993). When both succinate and methylamine were present in the growth medium, the expression of the mau genes decreased about 50fold, as compared to during growth on methylamine alone, although the amount of MauR was the same in both cases. These results indicate that MauR-dependent expression of the mau gene cluster is either blocked due to the presence of a repressor protein or not induced due to the absence of a second activator protein during growth on succinate. We favour the concept of a second activator which acts in synergism with MauR during transcriptional control of the mau genes. This concept is in agreement with our earlier studies where we described the isolation of a mutant impaired in the expression of both the mox and mau genes (Harms et al., 1996). This mutant was unable to grow on methanol or methylamine, and was unable to synthesize methanol dehydrogenase and $\mathrm{MADH}$ under inducing conditions [i.e. when the cells were grown in media containing choline as the carbon and energy source plus either methanol or methylamine (inducers)].

In cases where MauR is activated (in the presence of methylamine), the expression level of the mau gene cluster increases almost 40-fold (4 Miller units in succinate-grown cells versus 148 in those grown on methylamine and succinate). When the second activator is also active in addition to MauR, the expression level of the mau gene cluster increases another 50-fold (148 Miller units in succinate- and methylamine-grown cells versus 8755 in methylamine-grown cells). Thus when both transcription factors are present an approximately 2000-fold increase of gene expression (4 Miller units in succinate-grown cells versus 8755 in methylaminegrown cells) is achieved. During growth on choline, MauR is inactive (no methylamine), but the expression level of the mau genes is almost 10-fold higher as compared to succinate-grown cells, which may reflect a higher activity of the second activator in the former cells. When the cells are grown on a mixture of choline and methylamine, both MauR and the second activator are active, and the expression levels increase almost 100fold as compared to those of choline-grown cells. Apparently, the presence of choline still slightly suppresses the activity of the second activator, since the expression levels are half of those found during growth on methylamine alone. Exactly the same trends were observed when we analysed the data from the strains that had integrated the promoter-lac $Z$ fusions twice (all activities were doubled as compared to those with a single integration). We may therefore conclude that the DNA is still limiting in the control of gene expression, and that regulatory proteins are not diluted due to the integration of more than one copy of the target DNA. During growth of the mauR mutants on succinate or choline, the mauF promoter activities were comparable to those of the wild-type. Furthermore, these promoter activities did not change significantly when methylamine was added to the growth medium, supporting the proposed model that MauR is essential for methylamine-induced expression.

The mauR promoter activity is relatively constant during growth on either succinate or methylamine, but increases two- to threefold when choline is added to the growth medium. The reason for this stimulation is not known. It is notable that the same promoter activities were found in the wild-type and mauR mutant strains, indicating that mauR gene expression is not autoregulated. This feature makes the regulation of mauR unusual, since it has been described that the genes of many other LysR-type regulators are negatively autoregulated (Schell, 1993). The only exceptions that have been described concern mleR and $x a p R$ (Renault et al., 1989; Seeger et al., 1995).

The DNA-binding site of all LysR regulatory proteins consists of an inverted repeat including the $\mathrm{T}-\mathrm{N}_{11}-\mathrm{A}$ motif (LysR motif) (Goethals et al., 1992), except in the case of CatR, where the G-N $\mathrm{N}_{11}$-A motif (CAGACC- $\mathrm{N}_{5}$ GGT ATG) replaces the common T-N $\mathrm{N}_{11}$-A motif within the inverted repeat (Parsek et al., 1994). There is no LysR consensus motif in the mau promoter region. Only an inverted repeat containing a G-N $\mathrm{N}_{11}$-A motif (GGCA$\mathrm{N}_{5}$-TCC $\underline{A}$ ) was found 26 bp upstream of the start codon of the mauR gene.

Although the exact site of binding is still unknown, gel mobility shift assays demonstrated that MauR binds specifically to the mau promoter region. This event occurred even in the absence of the inducer, methylamine. These in vitro binding experiments showed that the presence of the inducer does not alter the 
apparent affinity of MauR for the mau promoter region, nor the mobility of the MauR-promoter-DNA complex as judged by the presence of one single retarded band exhibiting similar intensity and mobility, with or without methylamine. A similar lack of effect of the inducer on promoter-binding activity has also been reported for the LysR-type transcriptional activators NahR and CatM (Romero-Arroyo et al., 1995; Schell \& Faris Poser, 1989). However, in vivo footprinting experiments in the case of NahR revealed that the presence of its inducer caused further interactions of NahR with sequences downstream of the primary binding site $(-65)$, near position -40 (Huang \& Schell, 1991). The reason why we did not observe a methylamine-mediated change in our gel shift assays might be due to the fact that the differences in the band-shift induced by methylamine are too small. Another possible explanation is that the methylamine-mediated change occurs only when the second activator is also present to enhance specific DNA-binding properties of MauR.

Our current model, which accounts for all our observations, predicts that MauR is present under all growth conditions, and is activated when methylamine is bound as a coinducer molecule. Both forms are able to bind to the DNA, but they bind weakly. Only when MauR is in the active configuration can it make contact with the second activator. The resulting complex may bind firmly to the DNA as a prerequisite for promoting mau gene expression. Another example of a LysR-type activator acting together with a second activator to activate transcription has been described for the $d s d X A$ promoter (Nørregaard-Madsen et al., 1995). We are currently characterizing the second activator in order to confirm our model.

\section{ACKNOWLEDGEMENTS}

This research was supported by the Netherlands Foundation for Chemical Research with financial aid from the Netherlands Organization for the Advancement of Science. This work was performed, in part, under the auspices of the Human Capital and Mobility Network The Methylamine Dehydrogenase Redox Chain of Thiobacillus versutus, financed by the European Commission under contract ERB-CHR-XCT930189.

\section{REFERENCES}

Ausubel, F. M., Brent, R., Kingston, R. E., Moore, D. D., Seidman, J. G., Smith, J. A. \& Struhl, K. (1993). Current Protocols in Molecular Biology. New York: John Wiley.

Birnboim, H. C. (1983). A rapid alkaline extraction method for the isolation of plasmid DNA. Methods Enzymol 100, 243-255.

Boyer, H. W. \& Roulland-Dussoix, D. (1969). A complementation analysis of the restriction and modification of DNA in Escherichia coli. J Mol Biol 41, 459-472.

Chang, J. P. \& Morris, J. G. (1962). Studies on the utilization of nitrate by Micrococcus denitrificans. J Gen Microbiol 29, 301-310.

Chistoserdov, A. Y., Boyd, J., Mathews, F. S. \& Lidstrom, M. E. (1992). The genetic organization of the mau gene cluster of the facultative autotroph Paracoccus denitrificans. Biochem Biophys Res Commun 184, 1226-1234.

Chistoserdov, A. Y., Chistoserdova, L. V., McIntire, W. S. \& Lidstrom, M. E. (1994). Genetic organization of the mau gene cluster in Methylobacterium extorquens AM1: complete nucleotide sequence and generation and characteristics of mau mutants. $J$ Bacteriol 176, 4052-4065.

Coco, W. M., Parsek, M. R. \& Chakrabarty, A. M. (1994). Purification of the LysR family regulator, ClcR, and its interaction with the Pseudomonas putida clcABD chlorocatechol operon promoter. J Bacteriol 176, 5530-5533.

De Vries, G. E., Harms, N., Hoogendijk, J. \& Stouthamer, A. H. (1989). Isolation and characterization of Paracoccus denitrificans mutants with increased conjugation frequencies and pleiotropic loss of a n(GATC)n DNA-modifying property. Arch Microbiol $152,52-57$.

Ditta, G., Stanfield, S., Corbin, D. \& Helinski, D. R. (1980). Broad host range DNA cloning system for gram-negative bacteria: construction of a gene bank of Rhizobium meliloti. Proc Natl Acad Sci USA 77, 7347-7351.

Goethals, K., Montagu, M. V. \& Holsters, M. (1992). Conserved motifs in a divergent nod box of Azorhizobium caulinodans ORS571 reveal a common structure in promoters regulated by LysR-type proteins. Proc Natl Acad Sci USA 89, 1646-1650.

Harms, N. \& van Spanning, R. J. M. (1991). $C_{1}$ metabolism in Paracoccus denitrificans. Genetics of Paracoccus denitrificans. J Bioenerg Biomembr 23, 187-210.

Harms, N., Ras, J., Koning, S., Reijnders, W. N. M., Stouthamer, A. H. \& van Spanning, R. J. M. (1996). Genetics of C1 metabolism regulation in Paracoccus denitrificans. In Microbial Growth on C1 Compounds, pp. 126-132. Edited by M. E. Lidstrom \& F. R. Tabita. Dordrecht, The Netherlands: Kluwer Academic.

Henikoff, S., Haughn, G. W., Calvo, J. M. \& Wallace, J. C. (1988). A large family of bacterial activator proteins. Proc Natl Acad Sci USA 85, 6602-6606.

Huang, J. \& Schell, A. (1991). In vivo interactions of the NahR transcriptional activator with its target sequences: inducermediated changes in the transcription activation. $J$ Biol Chem 266, 10830-10838.

Huitema, F., Van Beeumen, J., Van Driessche, G., Duine, J. A. \& Canters, G. W. (1993). Cloning and sequencing of the gene coding for the large subunit of methylamine dehydrogenase from Thiobacillus versutus. J Bacteriol 175, 6254-6259.

Husain, M. \& Davidson, V. L. (1985). An inducible periplasmic blue copper protein from Paracoccus denitrificans: purification, properties, and physiological role. J Biol Chem 260, 14626-14629.

Husain, M. \& Davidson, V. L. (1987). Purification and properties of methylamine dehydrogenase from Paracoccus denitrificans. I Bacteriol 169, 1712-1717.

Kessler, B., de Lorenzo, V. \& Timmis, K. N. (1992). A general system to integrate lac $Z$ fusions into the chromosomes of gramnegative eubacteria : regulation of the $P m$ promoter of the TOL plasmid studied with all the controlling elements in monocopy. Mol Gen Genet 233, 293-301.

Laemmli, U. K. (1970). Cleavage of structural proteins during the assembly of the head of bacteriophage T4. Nature 227, 680-685. Lidstrom, M. E. \& Chistoserdov, A. Y. (1993). Molecular biology and genetics of methylamine dehydrogenases. In Microbial Growth on C1 Compounds, pp. 381-400. Edited by J. C. Murrell \& D. P. Kelly. Andover: Intercept.

McIntire, W. S., Wemmer, D. E., Chistoserdov, A. Y. \& Lidström, M. E. (1991). A new cofactor in a procaryotic enzyme: tryptophan- 
tryptophylquinone as the redox prosthetic group in methylamine dehydrogenase. Science 252, 817-824.

Malakooti, J. \& Ely, B. (1994). Identification and characterization of the ilvR gene encoding a LysR-type regulator of Caulobacter crescentus. J Bacteriol 176, 1275-1281.

Miller, J. H. (1972). Experiments in Molecular Genetics. Cold Spring Harbor, NY: Cold Spring Harbor Laboratory.

Nørregaard-Madsen, M., McFall, E. \& Valentin-Hansen, P. (1995). Organization and transcriptional regulation of the Escherichia coli K-12 D-serine tolerance locus. J Bacteriol 177, 6456-6461.

Page, M. D. \& Ferguson, S. J. (1993). Mutants of Methylobacterium extorquens and Paracoccus denitrificans deficient in $c$ type cytochrome biogenesis synthesise the methylamine-dehydrogenase polypeptides but cannot assemble the tryptophan-tryptophylquinone group. Eur J Biochem 218, 711-717.

Parke, D. (1996). Characterization of PcaQ, a LysR-type transcriptional activator required for catabolism of phenolic compounds from Agrobacterium tumefaciens. J Bacteriol 178, 266272.

Parsek, M. R., Ye, R. W., Pun, P. \& Chakrabarty, A. M. (1994). Critical nucleotides in the interaction of a LysR-type regulator with its target promoter region: catBC promoter activation by CatR. J Biol Chem 269, 11279-11284.

Parsek, M. R., Kivisaar, M. \& Chakrabarty, A. M. (1995). Differential DNA bending introduced by the Pseudomonas putida LysR-type regulator, CatR, at the plasmid-borne $p h e B A$ and chromosomal catBC promoters. Mol Microbiol 15, 819-828.

Renault, P., Gaillardin, C. \& Heslot, H. (1989). Product of the Lactococcus lactis gene required for malolactic fermentation is homologous to a family of positive regulators. J Bacteriol 171, 3108-3114.

Romero-Arroyo, C. E., Schell, M. A., Gaines, G. L. \& Neidle, E. L. (1995). cat $M$ encodes a LysR-type transcriptional activator regulating catechol degradation in Acinetobacter calcoaceticus. I Bacteriol 177, 5891-5898.

Sambrook, J., Fritsch, E. F. \& Maniatis, T. (1989). Molecular Cloning: a Laboratory Manual, 2nd edn. Cold Spring Harbor, NY : Cold Spring Harbor Laboratory.

Schell, M. A. (1993). Molecular biology of the LysR family of transcriptional regulators. Annu Rev Microbiol 47, 597-626.

Schell, M. A. \& Faris Poser, E. (1989). Demonstration, characterization, and mutational analysis of NahR protein binding to $n a b$ and sal promoters. J Bacteriol 171, 837-846.

Seeger, C., Poulsen, C. \& Dandanell, G. (1995). Identification and characterization of genes ( $x a p A, x a p B$ and $x a p R)$ involved in xanthosine catabolism in Escherichia coli. J Bacteriol 177, 5506-5516.

Southern, E. M. (1975). Detection of specific sequences among DNA fragments separated by gel electrophoresis. $J$ Mol Biol 98, 503-517.

van Spanning, R. J. M., Wansell, C. W., Harms, N., Oltmann, L. F. \& Stouthamer, A. H. (1990a). Mutagenesis of the gene encoding cytochrome $c 550$ of Paracoccus denitrificans and analysis of the resultant physiological effects. J Bacteriol 172, 986-996.

van Spanning, R. J. M., Wansell, C. W., Reijnders, W. N. M., Oltmann, L. F. \& Stouthamer, A. H. (1990b). Mutagenesis of the gene encoding amicyanin of Paracoccus denitrificans and the resultant effect on methylamine oxidation. FEBS Lett 275, 217-220.

van Spanning, R. J. M., Van der Palen, C. J. N. M., Slotboom, D. J., Reijnders, W. N. M., Stouthamer, A. H. \& Duine, J. A. (1994). Expression of the mau genes involved in methylamine metabolism in Paracoccus denitrificans is under control of a LysR-type transcriptional activator. Eur J Biochem 226, 201-210.

Studier, F. W., Rosenberg, A. H., Dunn, J. J. \& Dubendorff, J. W. (1990). Use of T7 RNA polymerase to direct the expression of cloned genes. Methods Enzymol 185, 60-89.

Towbin, H., Staehelin, T. \& Gordon, J. (1979). Electrophoretic transfer of proteins from polyacrylamide gels to nitrocellulose sheets : procedure and some applications. Proc Natl Acad Sci USA 76, 4350-4354.

Ubbink, M., Van Kleef, M. A. G., Kleinjan, D.-J., Hoitink, C. W. G., Huitema, F., Beintema, J. J., Duine, J. A. \& Canters, G. W. (1991). Cloning, sequencing and expression studies of the genes encoding amicyanin and the $\beta$-subunit of methylamine dehydrogenase from Thiobacillus versutus. Eur J Biochem 202, 1003-1012.

Van der Palen, C. J. N. M., Slotboom, D.-J., Jongejan, L., Reijnders, W. N. M., Harms, N., Duine, J. A. \& van Spanning, R. J. M. (1995). Mutational analysis of mau genes involved in methylamine metabolism in Paracoccus denitrificans. Eur $J$ Biochem 230, 860-871.

Wang, L., Helmann, J. D. \& Winans, S. C. (1992). The $A$. tumefaciens transcriptional activator OccR causes a bend at a target promoter, which is partially relaxed by a plant tumor metabolite. Cell 69, 659-667.

Received 2 September 1996; revised 8 October 1996; accepted 11 October 1996. 